\title{
ANALISIS PROFITABILITAS PADA PT UNILEVER INDONESIA, TBK
}

\author{
Vargo Christian L. Tobing \\ Universitas Putera Batam \\ email: vargo.tobing@gmail.com
}

\begin{abstract}
The purpose of this research is to determine the performance of PT Unilever Indonesia as seen from the company's ability to generate profits. The financial statements studied are financial reports that have been published on IDX. The periode of the financial statements studied is a period of 5 years, from 2014 to 2018. From the results of the study, it can be seen that the company's ability to generate profits can be concluded very well. This is because trends resulting from profit margin ratios and return on assets show an upward trend in profits. The return on equity profit ratio does not invrease. However, the company still gets a high profit
\end{abstract}

Keywords: Net Profit Margin, Return On Asset, Return On Equity

\section{PENDAHULUAN}

Profitabilitas merupakan suatu rasio yang digunakan oleh investor ataupun pengguna laporan keuangan lainnya untuk mengetahui seberapa besar kemampuan perusahaan dalam memperoleh keuntungan. Bagi Investor ataupun calon investor, penting untuk mengetahui kemampulabaan suatu perusahaan agar investasi dana yang dilakukan dapat memberikan keuntungan bagi investor, hal ini dikarenakan investor hanya akan mendapatkan keuntungan pembagian laba (dividen) jika perusahaan memperoleh keuntungan. Sebaliknya, jika perusahaan menderita kerugian, maka investor tidak akan memperoleh pembagian laba (dividen). Kondisi merugi seperti inilah sebisa mungkin akan dihindari oleh investor.

Profitabilitas merupakan suatu berita penting yang bisa dipakai bagi investor dalam estimasi dalam rangka melakukan penanaman modal, dan adalah suatu penunjuk kesuksesan operasi suatu kegiatan usaha sebab profitabilitas merepresentasikan derajat efektivitas yang telah diperoleh perusahaan (Nurmiati, 2016 dalam Carolina dan Tobing , 2019)

Unilever merupakan perusahaan consumer goods yang memiliki kinerja baik dalam hal keuangan. Produk-produk Unilever menguasai banyak diminati oleh masyarakat Indonesia. Penelitian ini dilakukan untuk melihat sejauh mana kemampuan profitabilitas perusahaan Unilever dalam menghasilkan keuntungan.

\section{TINJAUAN PUSTAKA}

\section{Profitabilitas}

Profitabilitas merupakan rasio yang digunakan untuk menilai efektivitas suatu kegiatan usaha dalam mendapatkan laba pada tingkat asset, penjualan, maupun ekuitas saham. Rasio ini dimana mempunyai tujuan menghitung nilai potensi manajemen dalam menjalankan operasional di perusahaan (Hanafi dan Halim, 2016:81) 
2016:81) :

Adapun jenis-jenis rasio profitabilitas adalah sebagai berikut (Hanafi dan Halim,

1. Net profit margin

Menghitung sejauh mana kemampuan perusahaan menghasilkan laba bersih pada tingkat penjualan tertentu.

Adapun rumus yang digunakan untuk menghitung net profit margin adalah sebagai berikut

Profit Margin $=\frac{\text { Lababersih }}{\text { Penjwalan }}$

2. Return On Asset

Rasio ini digunakan untuk mengukur kemampuan perusahaan menghasilkan laba bersih berdasarkan tingkat asset yang tertentu

Adapun rumus yang digunakan untuk menghitung return on asset adalah sebagai berikut:

Return On Asset $=\frac{\text { Lababersih }}{\text { Total Aset }}$

3. Return On Equity

Rasio ini digunakan untuk mengukur kemampuan perusahaan menghasilkan laba bersih berdasarkan modal saham tertentu

Adapun rumus yang digunakan untuk menghitung return on equity adalah sebagai berikut:

Return On Asset $=\frac{\text { Lababersih }}{\text { Modalsaham }}$

\section{METODE}

Penelitian ini adalah penelitian deskriptif kualitatif. Objek yang digunakan dalam penelitian ini adalah PT Unilever Indonesia, Tbk dengan objek yang diteliti adalah laporan keuangan perusahaan untuk melihat kemampuan perusahaan dalam menghasilkan laba.

\section{HASIL DAN PEMBAHASAN} berikut:

Adapun hasil dari perhitungan analisis profitabilitas pada perusahaan adalah sebagai

1. Net profit margin

Net profit margin yang dihasilkan oleh perusahaan tampak sebagai berikut:

\begin{tabular}{|l|l|}
\hline Tahun & Net Profit Margin (\%) \\
\hline 2014 & 16,63 \\
\hline 2015 & 16,04 \\
\hline 2016 & 15,96 \\
\hline 2017 & 17,00 \\
\hline 2018 & 21,79 \\
\hline
\end{tabular}

Dari tabel di atas, dapat kita lihat bahwa:

Tahun 2014, net profit margin yang dihasilkan oleh perusahaan sebesar 16,63\%, ini artinya, perusahaan mampu menghasilkan keuntungan sebesar $16,63 \%$ dari total penjualan.

Tahun 2015, net profit margin perusahaan sebesar 16,04\%, jika dibandingkan dengan tahun 2014, profit margin tahun 2015 mengalami penurunan sebesar 0,59\%. Hal ini menunjukkan bahwa ada sedikit penurunan kemampuan perusahaan dalam menghasilkan laba 
Tahun 2016, net profit margin perusahaan sebesar 15,96\%, jika dibandingkan dengan tahun 2015, profit margin tahun 2016 mengalami penurunan sebesar $0,08 \%$. Hal ini menunjukkan bahwa ada sedikit penurunan kemampuan perusahaan dalam menghasilkan laba.

Tahun 2017, net profit margin perusahaan sebesar 17\%, jika dibandingkan dengan tahun 2016, profit margin tahun 2017 mengalami kenaikan sebesar 1,04\%. Hal ini menunjukkan bahwa terjadi peningkatan kemampuan perusahaan dalam menghasilkan keuntungan yang dilihat dari penjualan. Dan keuntungan tahun 2017 ini merupakan keuntungan yang lebih besar dibandingkan keuntungan yang diperoleh dari tahun 2014 sampai dengan 2016

Tahun 2018, net profit margin perusahaan sebesar 21,79\%, jika dibandingkan dengan tahun 2017, profit margin tahun 2018 mengalami kenaikan yang signifikan, yaitu sebesar 4,79\%. Hal ini menunjukkan bahwa terjadi peningkatan kemampuan perusahaan dalam menghasilkan keuntungan yang dilihat dari penjualan. Dan keuntungan tahun 2018 ini merupakan keuntungan yang lebih besar dibandingkan keuntungan yang diperoleh dari tahun 2014 sampai dengan 2017.

Kemampuan perusahaan dalam menghasilkan keuntungan jika dilihat dari net profit margin adalah baik karena memiliki tren yang naik. Tren dapat dilihat pada gambar berikut:

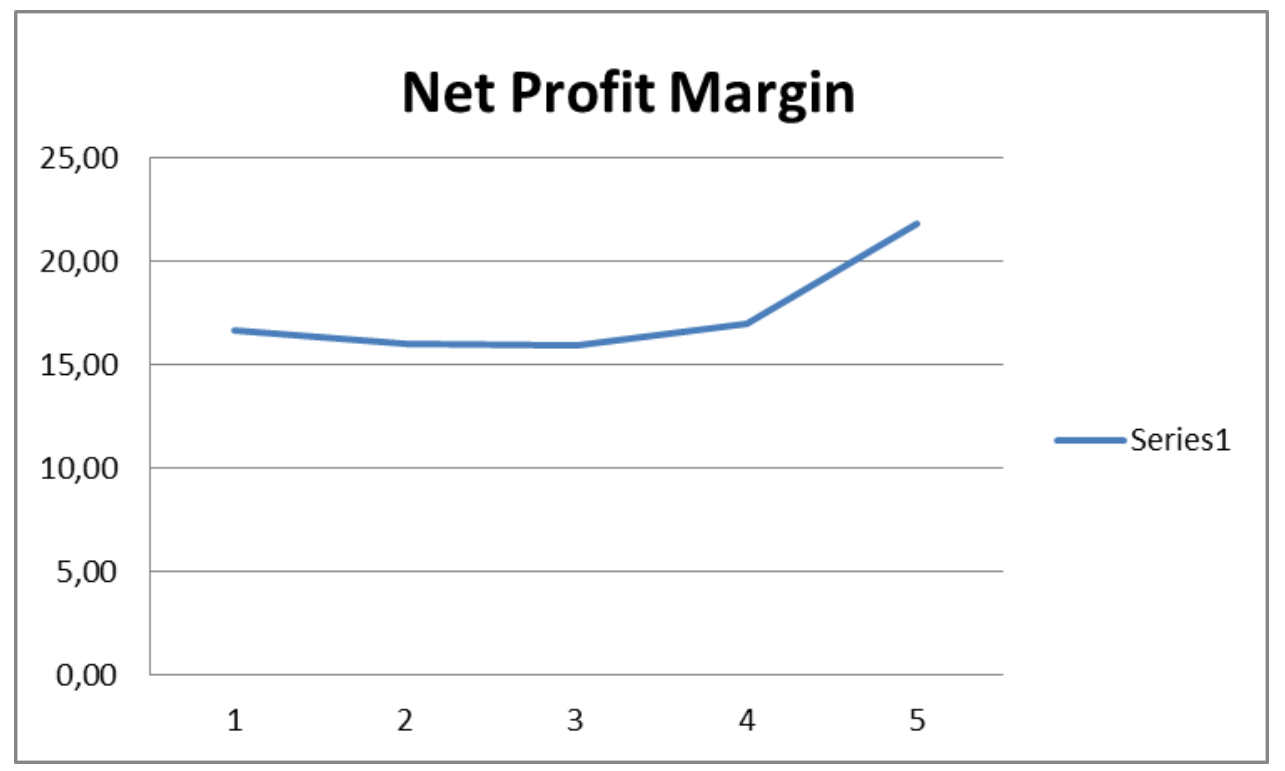

2. Return on Asset

Return on Asset yang dihasilkan oleh perusahaan tampak sebagai berikut:

\begin{tabular}{|l|l|}
\hline Tahun & Return on Asset (\%) \\
\hline 2014 & 40,18 \\
\hline 2015 & 37,20 \\
\hline 2016 & 38,16 \\
\hline 2017 & 37,05 \\
\hline 2018 & 46,66 \\
\hline
\end{tabular}


Dari tabel di atas, dapat kita lihat bahwa:

Tahun 2014, return on asset yang dihasilkan oleh perusahaan sebesar 40,18\%, ini artinya, perusahaan mampu menghasilkan keuntungan sebesar $40,18 \%$ dari total aktiva yang dimiliki.

Tahun 2015 , return on asset perusahaan sebesar 37,20\%, jika dibandingkan dengan tahun 2014, return on asset tahun 2015 mengalami penurunan sebesar 2,98\%. Hal ini menunjukkan bahwa ada sedikit penurunan kemampuan perusahaan dalam menghasilkan laba

Tahun 2016, return on asset perusahaan sebesar 38,16\%, jika dibandingkan dengan tahun 2015, return on asset tahun 2016 mengalami kenaikan sebesar $0,96 \%$. Hal ini menunjukkan bahwa ada peningkatan kemampuan perusahaan dalam menghasilkan laba

Tahun 2017, return on asset perusahaan sebesar 37,05\%, jika dibandingkan dengan tahun 2016, return on asset tahun 2017 mengalami penurunan sebesar $1,11 \%$. Hal ini menunjukkan bahwa ada penurunan kemampuan perusahaan dalam menghasilkan laba

Tahun 2018, return on asset perusahaan sebesar 46,66\%, jika dibandingkan dengan tahun 2017, return on asset tahun 2018 mengalami kenaikan sebesar 9,61\%. Hal ini menunjukkan bahwa ada peningkatan kemampuan perusahaan dalam menghasilkan laba. Peningkatan keuntungan perusahaan tahun 2018 mengalami kenaikan yang signifikan dibandingkan dari tahun sebelumnya.

Kemampuan perusahaan dalam menghasilkan keuntungan jika dilihat dari return on asset adalah baik karena memiliki tren yang naik. Tren dapat dilihat pada gambar berikut:

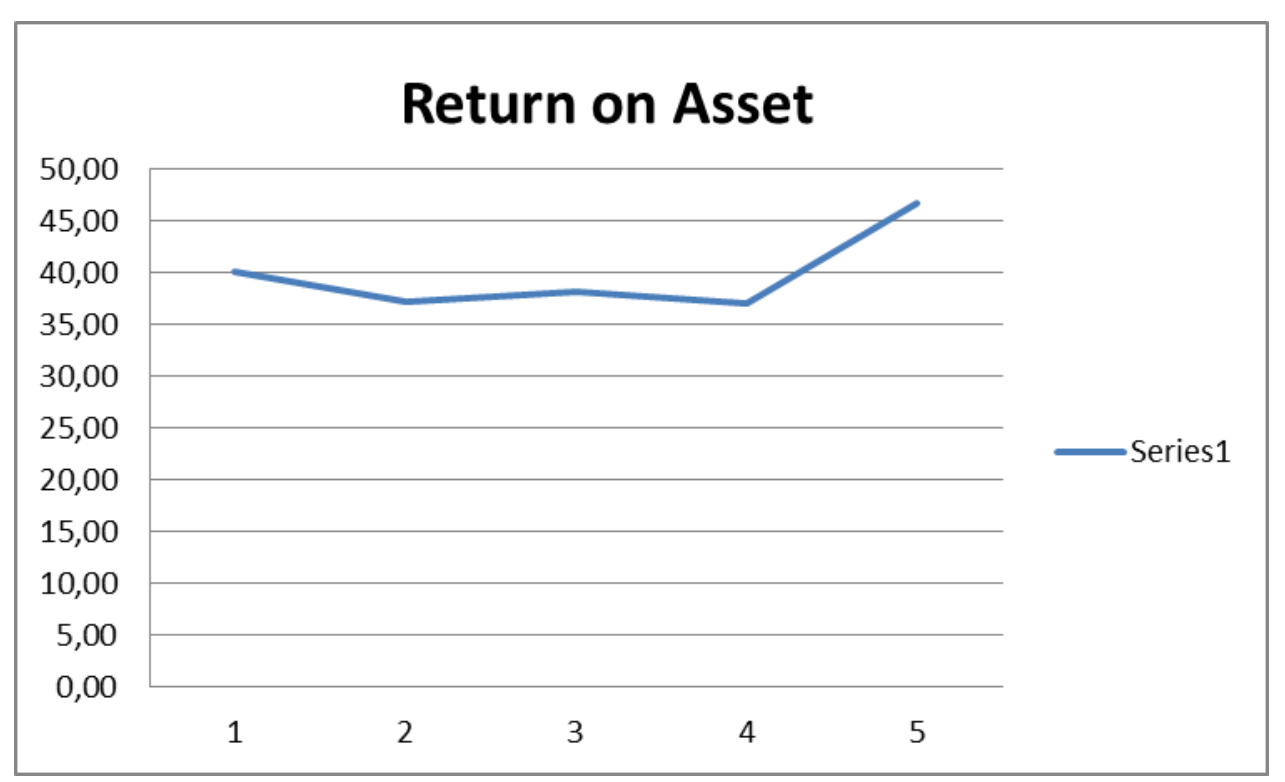

3. Return on Equity

Return on equity yang dihasilkan oleh perusahaan tampak sebagai berikut:

\begin{tabular}{|l|l|}
\hline Tahun & Return on Equity (\%) \\
\hline 2014 & 124,78 \\
\hline 2015 & 121,22 \\
\hline
\end{tabular}




\begin{tabular}{|l|l|}
\hline 2016 & 135,85 \\
\hline 2017 & 135,40 \\
\hline 2018 & 120,21 \\
\hline
\end{tabular}

Dari tabel di atas, dapat kita lihat bahwa:

Tahun 2014, return on equity yang dihasilkan oleh perusahaan sebesar $124,78 \%$, ini artinya, perusahaan mampu menghasilkan keuntungan sebesar $124,78 \%$ dari modal yang dimiliki

Tahun 2015 , return on equity perusahaan sebesar $121,22 \%$, jika dibandingkan dengan tahun 2014, return on equity tahun 2015 mengalami penurunan sebesar 3,56\%. Hal ini menunjukkan bahwa ada sedikit penurunan kemampuan perusahaan dalam menghasilkan laba

Tahun 2016, return on equity perusahaan sebesar 135,85\%, jika dibandingkan dengan tahun 2015, return on equity tahun 2016 mengalami kenaikan sebesar 14,63\%. Hal ini menunjukkan bahwa kemampuan perusahaan dalam menghasilkan laba mengalami kenaikan yang signifikan.

Tahun 2017, return on equity perusahaan sebesar 135,40\%, jika dibandingkan dengan tahun 2016, return on equity tahun 2017 mengalami penurunan sebesar $0,45 \%$. Hal ini menunjukkan bahwa kemampuan perusahaan dalam menghasilkan laba mengalami penurunan

Tahun 2018 , return on equity perusahaan sebesar 120,21\%, jika dibandingkan dengan tahun 2017, return on equity tahun 2018 mengalami penurunan sebesar 15,19\%. Hal ini menunjukkan bahwa kemampuan perusahaan dalam menghasilkan laba mengalami penurunan yang signifikan

Kemampuan perusahaan dalam menghasilkan keuntungan jika dilihat dari return on equity adalah kurang baik karena memiliki tren yang menurun. Akan tetapi, jika dilihat dari nilai keuntungan yang diperoleh, perusahaan cukup baik dalam menghasilkan keuntungan. Tren dapat dilihat pada gambar berikut:

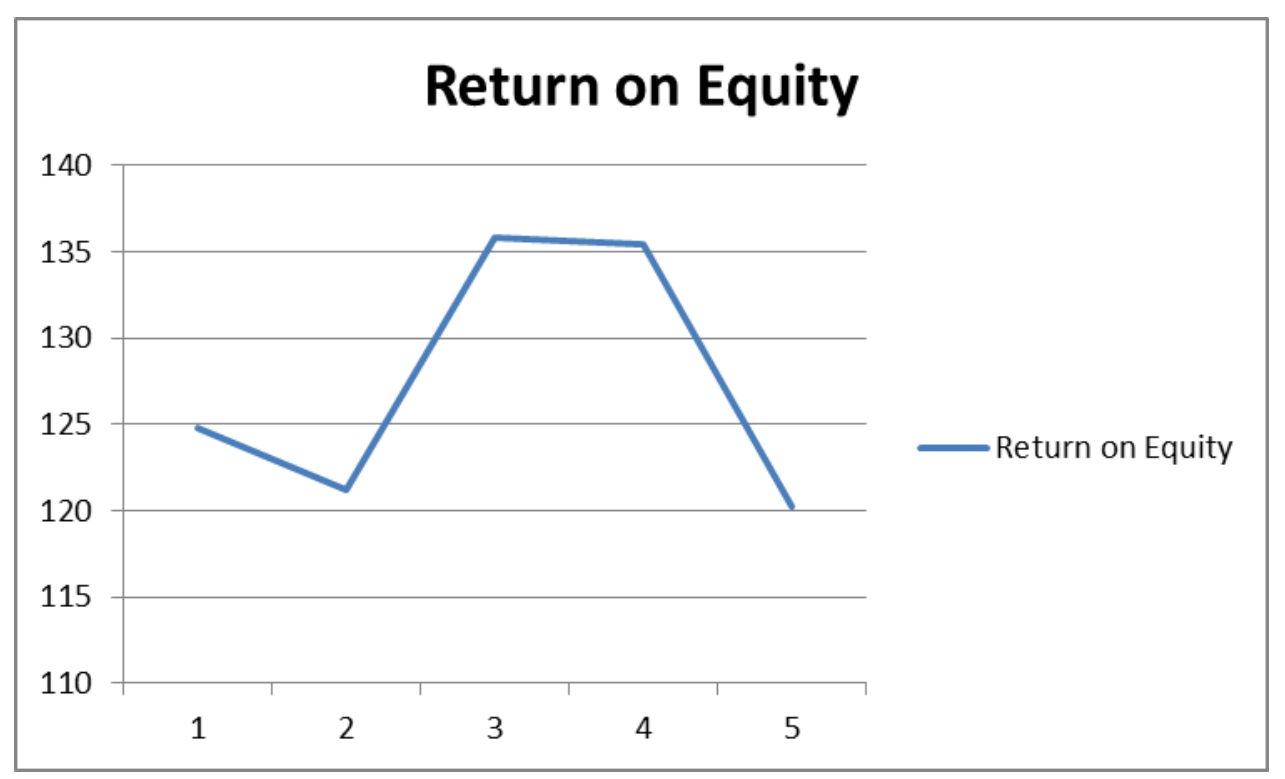




\section{SIMPULAN}

Dari hasil penelitian, dapat disimpulkan bahwa:

1. Kemampuan perusahaan dalam menghasilkan laba dilihat dari net profit margin menghasilkan keuntungan yang baik bagi perusahaan. Hal ini dapat dilihat dari tren yang dihasilkan dari rasio net profit margin yang meningkat

2. Kemampuan perusahaan dalam menghasilkan laba dilihat dari return on asset menghasilkan keuntungan yang baik bagi perusahaan. Hal ini dapat dilihat dari tren yang dihasilkan dari rasio return on asset yang meningkat

3. Kemampuan perusahaan dalam menghasilkan laba dilihat dari return on equity menghasilkan keuntungan yang kurang baik bagi perusahaan karena tren keuntungan dari rasio ini menurun. Akan tetapi, jika dilihat dari nilai keuntungan yang diperoleh, perusahaan cukup baik dalam menghasilkan keuntungan. perusahaan tidak pernah mengalami kerugian. Dapat dikatakan bahwa, secara keseluruhan, perusahaan memiliki kinerja yang bagus dalam menghasilkan keuntungan.

\section{DAFTAR PUSTAKA}

Carolina, Jessica dan L. Tobing (2019). Pengaruh profitabilitas, likuiditas, solvabilitas dan ukuran perusahaan terhadap ketepatan waktu penyampaian laporan keuangan pada perusahaan manufaktur di BEI. Jurnal Akuntansi Barelang. Volume 3, Nomor 2

Hanafi, M.M \& Halim, A. (2016). Analisis Laporan Keuangan. Yogyakarta: Penerbit : UPP STIM YKPN 